\title{
Another vaccine, another story: BCG vaccination against tuberculosis in India, 1948 to 1960
}

\author{
Outra vacina, outra história: \\ a vacinação de BCG contra tuberculose na Índia, 1948 a 1960
}

Niels Brimnes ${ }^{1}$

${ }^{1}$ Department of History and Area Studies, Aarhus University. Building 1410, Bartholins Allé 16. DK-8000 Aarthus C. Denmark.

hisnb@hum.au.dk

\begin{abstract}
Through an examination of mass BCG vaccination against tuberculosis in India between 1948 and 1960 this article draws attention to the diversity of the history of vaccination. The features of vaccination campaigns often differed from those of the celebrated campaign to eradicate smallpox. Due to differences between smallpox and tuberculosis as well as between the vaccines developed against them, an analysis of BCG mass vaccination against tuberculosis seems particularly well suited for this purpose. Three points of difference are identified. First, in non-Western contexts BCG vaccination procedures were modified to a greater extent than vaccination against smallpox. Second, tuberculosis lacked the drama and urgency of smallpox and BCG vaccination campaigns suffered more from recruitment problems than did the more "heroic" smallpox eradication campaign. Third, the BCG vaccine was contested in medical circles and was much better suited than the vaccine against smallpox as a vehicle for the articulation of concerns about postcolonial modernization.
\end{abstract}

Key words Vaccination, Tuberculosis, BCG, International public health, India
Resumo Através da observação da vacinação em massa de BCG contra a tuberculose na Índia durante os anos de 1948 a 1960, este artigo chama a atenção para a diversidade da história da vacinação. As características das campanhas de vacinação geralmente diferem daquelas celebradas nas campanhas para erradicação da varíola. Devido às diferenças entre a varíola e a turberculose, assim como entre as vacinas desenvolvidas para combater essas doenças, uma análise da vacinação em massa de BCG contra a turberculose parece especialmente bem situada para essa proposta. Três pontos de diferença foram identificados. O primeiro é que em contextos não ocidentais os procedimentos da vacinação de BCG foram modificados em uma extensão maior do que a vacinação contra a varíola. Em segundo lugar, a tuberculose não tinha o drama e a urgência da variola, e as campanhas de vacinação de BCG sofreram mais com problemas de recrutamento do que a mais "heroica" campanha de erradicação da varíola. $E$ por último, a vacina de BCG foi contestada em círculos médicos e foi muito mais bem adaptada do que a vacina contra variola como um veículo para articulação de preocupações sobre a modernização pós-colonial.

Palavras-chave Vacinação, Tuberculose, BCG, Saúde pública internacional, Índia 


\section{Introduction}

If the term "vaccination" originally referred specifically to the insertion of cowpox virus into the human body in order to prevent smallpox, the term has since assumed a broader meaning. Today, any administration of weakened, killed or fragmented microorganisms with the purpose of preventing disease is commonly known as "vaccination" 1 . The history of vaccination is therefore highly diverse, as it encompasses the medical, social and political contexts of a variety of diseases and the employment of equally different vaccines developed to protect against these diseases. In this article, I will examine the mass BCG vaccination campaign against tuberculosis in India in the first decade after independence. Throughout the 1950s BCG vaccination was high on the WHO agenda and the vaccine received more attention than any other vaccine; including the "original" vaccine against smallpox. Tuberculosis and smallpox are very different diseases and so are the vaccines developed against them. A study of the BCG campaigns offers, therefore, a valuable perspective on the narratives of vaccination against smallpox. Moreover, the BCG campaigns of the 1950s were carried out with much assistance and interest from UN-organisations in the decade before WHO launched the campaign to eradicate smallpox through a massive vaccination effort. In this sense the mass BCG campaigns formed part of the prelude to the eradication of smallpox.

\section{Different diseases, different vaccines}

Smallpox was caused by a virus (variola major), the onset of disease occurred within one to two weeks after infection and its course was dramatic with sudden high fever, skin eruptions and pustules. Smallpox killed up to 30 per cent of its victims, normally within two weeks after the first symptoms had occurred and many of those who survived were blinded or disfigured for life. Survivors were, however, immune to future attacks, and this in effect made smallpox a children's disease. Smallpox raged equally in all social classes: perhaps the only protection offered by a higher standard of living was the opportunity to avoid crowded conditions ${ }^{2,3}$. The vaccines developed in continuation of Jenner's discovery, have been praised as being among medicine's most successful prophylactics, providing long-lasting and complete protection against the disease ${ }^{4}$. It would be hopelessly simplistic to view vaccination against smallpox as an infallible and globally uniform procedure. Particularly in the nineteenth century vaccination often failed and was performed in different ways in different contexts; but after the advent of the freeze-dried vaccine in the second half of the $20^{\text {th }}$ century vaccination against smallpox became a relatively simple and uniform affair ${ }^{3,5,6}$.

Tuberculosis is caused by a bacteria (mycobacterium tuberculosis). While severe childhood forms of tuberculosis does exist, the most common form - pulmonary tuberculosis - occurs in adults. Pulmonary tuberculosis can develop many years after primary infection when symptoms such as lack of energy, loss of weight, fever, night sweats and cough occur. In the majority of those infected the immune system is, however, able permanently to "wall off" the infection. WHO estimates that while a third of the world's population might currently be infected with tuberculosis bacteria, only 5-10 per cent of those will become sick during their lifetime (provided that they are not infected with HIV $)^{7,8}$. Tuberculosis is, therefore, much less dramatic than smallpox: infected persons can carry the bacteria for years before any symptoms occur and when they occur, they do so gradually and it can be difficult to distinguish tuberculosis from other conditions. Indeed, as Halfdan Mahler - serving as the senior WHO officer to the BCG campaign In India from 1951 to 1955 - complained, part of the tuberculosis problem lay in the fact that the disease was "such a nice unspectacular killer". By contrast to smallpox, tuberculosis is a social disease. Despite some well known victims from the upper layers of society, it is mainly a problem for undernourished people, living in inadequate and crowded housing conditions. Tuberculosis takes its toll among those, whose immune system is too weak to resist the disease and this is one of the reasons why it is today mainly a problem in the developing countries in Asia and Africa.

The vaccine against tuberculosis came much later than the vaccine against smallpox. In 1921 French scientists Calmette and Guerin began to use a vaccine - called Bacillus Calmette-Guerin or BCG - which they claimed would help to prevent tuberculosis. If Jenner's discovery was soon hailed as a major medical breakthrough, the early years of BCG was, by contrast, fraught with doubts and controversy. It was soon clear that BCG did not provide a guarantee against developing tuberculosis. Debates on BCG were always about the "degree of protection" conferred by successful vaccination. Advocates of BCG claimed 
a protective effect of up to $80 \%$ for the vaccine, while its adversaries held that the vaccine offered no or little protection. At most, therefore, BCG was seen as tool to "control" tuberculosis, not as "a means of eradication". Before WWII there was a widespread concern that the living - though attenuated - bacteria could be harmful, because they might invigorate a "dormant" infection. These concerns were greatly amplified by the so-called Lübeck tragedy in 1930 when 76 infants died after being vaccinated with BCG. Although investigations into the issue cleared the vaccine suspicion lingered into the post-war period. From the 1940s most experts regarded BCG as safe, but doubts about the efficacy of the vaccine continued to fuel controversy ${ }^{10-12}$.

Up to the middle of the 1960s BCG would, for a number of reasons, not be given to already infected persons. First, vaccination would be ineffective in already infected individuals. Second, if an infected person was vaccinated and later developed tuberculosis, it would jeopardize an already controversial vaccine. Third, the doubts about the ability of BCG to a invigorate "dormant" infection had not been put entirely to rest. Finally, vaccination of infected individuals was avoided in order to prevent local inflammatory reactions. As a large number of healthy persons were infected with the bacteria, BCG vaccination involved a process of separating infected from uninfected. This was done through a series of tuberculin tests. If tuberculin were injected under the skin of an infected person there would be a reaction. When BCG for the first time was applied in mass vaccination programmes in postwar Europe two tests were conducted, and - by contrast to vaccination against smallpox - BCG vaccination required three visits to the same locality within a short time span.

Due to differences both in the nature of the two diseases and between the vaccines developed against them, the trajectories of the vaccination campaigns against smallpox and tuberculosis were also different. This article outlines the features of the largest vaccination campaign of the 1950: the BCG-campaign in India and seeks to identify points of difference between this campaign and the later effort to eradicate smallpox through vaccination.

\section{The BCG campaign in India}

In May 1948 the Government of India issued a press note stating that tuberculosis was "assum- ing epidemic proportions" in the country, and that it had "after careful consideration" decided to introduce BCG vaccination on a limited scale and under strict supervision as a measure to control the disease ${ }^{13}$. In August the first vaccinations were conducted and in November the efforts to introduce BCG intensified when India entered into an agreement with the Scandinavian vaccination initiative "The International Tuberculosis Campaign" (ITC) on a campaign demonstrating BCG to Indian doctors. Originally ITC was established to vaccinate in war-ravaged Europe, but substantial funding from Unicef entailed an obligation to expand the activities to areas outside Europe. From February 1949 five Scandinavian teams demonstrated BCG vaccination in various urban centres. Originally intended as a six month demonstration campaign, the Scandinavians stayed in India until the end of June $1951^{14}$.

From July 1951 BCG vaccination was conducted by the Indian authorities in close cooperation with Unicef, which continued to provide financial support, and WHO, which gave technical advice. It was generally perceived that, after the departure of ITC, the demonstration period was over and "real" mass vaccination about to begin. The Indian authorities, for one, calculated on an expanding campaign. The target for the first plan period was to reach 70 million tuberculin tests and by the end of the second plan period in 1961 the whole population below 25 years (estimated at 170 million) was expected to have been covered $^{15,16}$. In other words, it was expected to take a decade of carefully planned, standardized and scientifically sound vaccination work to vaccinate the Indian masses.

When ITC left the number of teams in the field had grown to 107 . They tested approximately 280,000 per month, or an average slightly above 2,500 monthly tests per team. In the new set-up the number of teams - now labelled "mass campaign units" - was dramatically reduced, but those left worked much more efficiently. According to Mahler's figures 15 of the new units conducted 275,000 monthly test; an average of 18,000 per team ${ }^{17,18}$. The campaign was not, however, simply expanding. While the total number of tests culminated in early 1955 with more than 2 million every month; the output per team never rose above the level from 1951. Mahler believed that teams in a smoothly running campaign could perform 30,000 monthly tests, but this target was never reached. An obvious reason this was that the campaign was moving out of urban centres to rural areas, where the population was much 
harder to reach. Less predictable incidents also influenced the output of the campaign. In July 1955, Mahler's successor as supervisor of the campaign, P. Mohamed Ali, had to explain a significant decrease in the number of tests, which were 250,000 below the previous quarter and 900,000 below the official target. He mainly pointed to a serious outbreak of anti-BCG propaganda in Madras, but he also suggested a range of other obstacles: the monsoon had set in early, it was marriage season in the North, schools were closed for summer vacation and smallpox epidemics disrupted life $\mathrm{e}^{19}$. A year later the reorganization of the Indian states adversely affected the campaign $^{20}$. To this the Unicef field officer in New Delhi added the high number of broken down vans. He claimed that $35 \%$ of all "vehicle days" were lost ${ }^{21}$. This catalogue of problems suggests that the BCG campaign in India was anything but a smoothly running and well-oiled machine ${ }^{22}$. To the contrary, in 1960 a somewhat disillusioned Mohamed Ali accepted: "hardly any quarter goes by without some major incident upsetting even the most carefully laid plans" ${ }^{23}$. By the end of the second plan period in 1961, the target of covering the entire and steadily growing population under 25 years was, therefore, not in sight and the campaign continued into the following decade. By the end of 1963 the total number of tests had gone beyond 200 million, and the campaign was still running ${ }^{24}$. Instead of following the campaign into the 1960s, however, I will consider in more detail some features of the BCG campaign in India in the 1950s.

\section{Adapting to realities on the ground}

The BCG campaign in India was the first and biggest outside Europe and it was therefore an exercise in transplanting a set-up, which had been developed in post-war Europe, to a poor and populous developing country. Adapting to Indian conditions was not straightforward because international experts and bureaucrats preferred a maximum of uniformity between campaigns in different parts of the world. There were two reasons for this. First, the safety and efficacy of BCG was still contested and it was deemed important to protect the reputation of BCG, and more particularly of the apparently highly efficacious Danish strain of the vaccine. Any deviation from the standard procedure involved a risk that the vaccine would appear to be without effect or even unsafe. An ITC report to Unicef explained "if mass vaccination is to be carried out without complications which would make the vaccination unpopular or even impossible, the best technique must be used" 25 . Second, the WHO in particular was eager to use data from ITC campaigns for scientific epidemiological research. Thus, in its Second Annual Report ITC declared:

For the first time in history, tuberculin testing and vaccination is carried out on a broad scale internationally with practically the same material, the same techniques, and with personnel who had received substantially the same instruction. It was the responsibility of ITC to ensure that records were kept and data compiled in a proper and uniform manner [...] In order to achieve the highest possible degree of uniformity in the statistical analyses made in the different countries ITC sent out trained statisticians to start the work and to train local statistical personnel ${ }^{26}$.

Despite this ideal of uniformity, it was unavoidable to make concessions to the realities on the ground in India. This happened mainly during the initial ITC phase of the campaign. Very early in the campaign one of the two tuberculin tests was abandoned. ITC's Second Annual Report explained: It is evident from the campaign to date that a two-test method of tuberculin testing before vaccination is not practical in a country like India, because too many people will not attend three times. A one-test method is an absolute condition for carrying out a mass campaign successfully in this country ${ }^{26}$. Similarly, the elaborate collection of statistical information practised in Europe was skipped. Instead of filling in cards for every person turning up for the tuberculin test, a mark was made directly on the body, and cards containing a minimum of information were used only for those actually vaccinated. The practice incorporating these changes was designated "the simplified technique" by ITC and recommended as a new uniform standard for mass vaccination campaigns ${ }^{27}$.

The use of qualified medical personnel was another area where the realities in India necessitated adaptation. In the European campaigns only qualified doctors and nurses had been allowed to perform tests and vaccinations. In India, which severely lacked medical personnel, this was clearly an untenable strategy. Not surprisingly the idea to use semi-skilled staff - or lay-vaccinators was aired before ITC as early as August 1949. It was presented as a wish from the Indian authorities and supported with reference to the fact that semi-skilled staff was successfully used in other vaccination campaigns (e.g. against smallpox $)^{28}$. 
The suggestion was met with some reluctance both from Scandinavian doctors and Indian authorities. From Delhi it was reported that the Director of Health in Uttar Pradesh and the Regional Director of WHO would strongly oppose any attempt to employ lay-vaccinators ${ }^{29,30}$. Still, P.V. Benjamin, tuberculosis advisor to the Indian government, advocated their use in a conference for tuberculosis workers held in November 1949. He pointed to "intelligent youngmen [sic] and women" as groups that could serve as lay vaccinators. He also referred to a suggestion from Uttar Pradesh that ayurvedic practitioners known as "vaids" - be employed as vaccinators. In apparent contrast to the opinion of the Director of Health in that state, Benjamin found that "This can be done, provided that they can work under the supervision of medical men trained in modern medicine" ${ }^{31}$. In 1950 it was agreed that vaccination teams could be composed of semitrained staff working under the supervision of a qualified doctor, and ITC began to employ layvaccinators on a limited probationary basis in the South Indian state of Travancore ${ }^{32}$. In the Second Annual Report, which covered the period up to July 1950, the judgement over semi-trained groups was positive. It was noted that tests and vaccination were carried out more satisfactorily by semi-trained staff than by fully qualified doctors, because the former were more likely to follow instructions. ITC recommended, therefore, that lay-vaccinators should be employed in countries, where a general shortage of qualified personnel otherwise made mass vaccination impossible ${ }^{26}$. When ITC director Johannes Holm returned from his visit to India in April 1951 he also reported favourably on their performance:

During my stay in India, I discussed this problem in a number of States where lay vaccinators were used. The general impression I obtained from doctors who had seen them at work was that they are both technically capable of doing the work, completely reliable, and generally more willing than doctors and nurses [...] From discussions in the different States, from the reports of the ITC personnel, and from what I saw personally, I became convinced that lay vaccinators certainly can be used in mass vaccination campaigns, provided the right people are chosen, the correct training given, and sufficient supervision exercised ${ }^{32}$.

During this visit to India Holm had attended a conference of BCG in New Delhi and the recommendations from the conference also endorsed the use of lay-vaccinators, provided they be supervised by qualified doctors ${ }^{33}$. This con- clusion was repeated in a practical guide from 1953, and again in an official WHO publication from $1965^{27,34}$. Throughout the campaign the standard team consisted of one qualified doctor and six semi-skilled technicians.

These necessary concessions to the ground realities in India sacrificed the ideal of providing the highest medical standard to people irrespective of their social condition or the economic capacity of their country. Although vaccination against smallpox also varied between regions particularly in the $19^{\text {th }}$ century ${ }^{5}$ - the relative complexity of BCG meant that more adaptations had to be made in order to introduce this type of vaccination to poor and populous developing countries. Global BCG-vaccination was, in other words, less uniform than global vaccination against smallpox.

\section{Recruitment problems}

The lack of qualified practitioners was not the only impediment to the recruitment of suitable staff into the campaign. The reputation of BCG work as dull and without future career possibilities was another. Mahler and others often complained about the lack of a "fighting spirit" in the campaign; indeed Mahler saw the condition, which he dubbed "BCG-fed-up-ness", as one of the most serious threats to successful mass vaccination $^{35-37}$. In 1952 Mahler described the BCG field work as frustrating and monotonous, with irregular working hours and with staff living "a permanent gypsy life away from homes and families." He argued for a special BCG-allowance to field-workers and warned: It is only through creating a certain attractiveness of the BCG job that it is possible to get the right type of personnel and more important - to maintain the continuity of their services ${ }^{38}$. Three years later Mahler had to concede that the campaign had fought a loosing battle in trying to propagate a sound personnel policy which would ensure continuity of service, discipline and enthusiasm. The reality behind these statements were situations like the one in Madhya Pradesh where all three teams doctors had left campaign by 1953 and no replacements found. In Mysore four teams were still working, but all team doctors were dissatisfied and had asked for transfer ${ }^{36}$. The situation was not much better in Uttar Pradesh, from where it was reported that the 11 teams allotted to this state had no working discipline due to indifferent team doctors ${ }^{39}$. In the second half of the 1950s, absenteeism was 
identified as a serious problem for the campaign and the reports several times referred to the existence of "fatique" among the staff" ${ }^{40,41}$. At the end of the decade, with the campaign 18 per cent behind the target that would secure 170 million tests by the end of the second five year plan period, Mohamed Ali could not hide his resignation and wrote: As the BCG Vaccination Campaign has been going on for over ten years now, it was perhaps inevitable that a certain amount of fatigue and apathy would creep in ${ }^{42}$.

Seen from the campaign headquarters there was, however, a difference in the attitude shown by the team doctors and technicians. The team doctors were consistently described in very negative terms as "over dignified" and displaying a "high brow indifference" to their work ${ }^{39,43,44}$. Half of these doctors, Mahler asserted in his final report, had a harmful influence on the performance of their teams, through a negative attitude, neglect of their duties, and indifference to the technical standard of the work ${ }^{18}$. The technicians often young unmarried matriculates - fared better in Mahler's judgment, although he somewhat patronizingly emphasized the need to keep them under strict supervision. Echoing Holm's view quoted above, Mahler wrote the following assessment of the BCG technician:

It is from this kind of material India's rural masses eventually will benefit in achieving their right to mental, physical and social well-being. Unspoiled and unaffected by the attitude which seems to pervade many of the medically qualified team leaders, they convince the villagers through their spontaneity, fortitude and enthusiasm.

It is pleasantly amusing, though a blow to most doctors' professional conceit, that in India nonmedical auxiliaries, after thorough training in a practical public health measure, do a better and more conscientious job than doctors. But raw and vulnerable as they are, they need supervision, guidance and encouragement. In the absence of this and under the influence of daily homeopathic doses of team doctors' indifferent attitude, their working standards deteriorate quickly ${ }^{18}$.

Again, it seems possible to identify a difference between vaccination campaigns against smallpox and tuberculosis. Due to the drama of smallpox, the effect of vaccination was obvious and visible within a short period of time. Smallpox eradication had a heroic quality to it, and this made it easy for field workers to see themselves as crusaders in a noble cause. BCG officials, on the other hand, could neither believe nor claim that they offered protection against an im- mediate danger. They could merely offer a presumed increase in the resistance to a future and much more intangible health hazard. All mass vaccination campaigns might experience recruitment problems due "fatique" or "fed-up-ness", but the facts that tuberculosis was - in Mahler's expression - "such a nice unspectacular killer" and the degree of protection provided by BCG uncertain, clearly amplified these problems in the BCG campaign ${ }^{9}$.

\section{Resistance and opposition}

Mass BCG vaccination in India encountered various forms of resistance and opposition. One form - which hardly fits these terms - was the alleged indifference among the target population. In 1949, ITC's leading doctor in India, Svend K. Svendsen reported that "deep ignorance and superstition rendered the masses difficult to reach" ${ }^{\prime 5}$ an in the early 1950s Mahler referred to the popular attitude towards BCG as "indifferent", "reluctant" and "passive" ${ }^{\$, 38,46}$. In his final report Mahler again mentioned suspicion and indifference among rural people as a problem that had to be "eradicated"18.

A doctor working in Baroda in the early stages of the campaign, B.P. Vyas, suggested a number of reasons why people did not seek BCG more actively: it was voluntary, it was difficult to explain how BCG provided protection, Indians were less "medicine-minded" than people in other parts of the world, and the vaccine had no immediate and visible effect. More significantly, he noted that people did not fear tuberculosis to the same extent as they feared more dramatic diseases: There are no apparent epidemics of Tuberculosis as there are of Cholera and Plague, and even though tuberculosis kills far more people every year than what Cholera and Plague do, the process is so insidious that it does not arouse the same terror in the minds of the people as is done by Cholera and Plague ${ }^{47}$. Again, the efficient running of the BCG campaign was hampered by the fact that tuberculosis was an "unspectacular killer".

The campaign also faced more active forms of resistance. In some places counter propaganda referred to the Lübeck tragedy and in Orissa opposition initiated by a professor in Pathology almost brought the campaign to a standstill ${ }^{44}$. It seems that Indians were particularly suspicious about the motives behind a campaign sponsored by the Indian state and distant international organizations and projected their fear of harmful state intervention on to the campaign. Thus, it is 
striking that BCG vaccination was often associated with birth control. This link was mentioned by Mahler in reports from 1953 and 1954 - where BCG was known as "Birth-Control-Governmentguarantee"43 - and it reappeared in 1956 during a rural demonstration campaign in Uttar Pradesh. The result was, according to P. Mohamed Ali, "an unfortunate panic created in the minds of the illiterate public" ${ }^{\prime 0}$. In 1959 rumour again connected birth control measures with BCG. Mohamed Ali reported on the existence of a whispering campaign to the effect that teams of doctors were moving about the country "injecting poison into the blood of the people to keep the population down"48.

Most significantly, however, the Indian BCG campaign was met with a forcefully articulated and ideologically informed anti-BCG campaign radiating from Madras in the South. In February 1949 ITC was ready to inaugurate vaccinations in this area, but was immediately challenged in the local monthly publication People's Health, published by the former sanitary engineer and proclaimed Gandhian, A.V. Raman. As early as in the November 1948 issue of People's Health Raman had written an editorial, which attacked the general health policy of the Union Government. It was accused of being biased towards "technical" solutions: educating more doctors and nurses, building more hospitals and distributing more drugs. Instead, Raman argued, the government ought to give priority to basic sanitary reforms, such as the provision of clean drinking water, proper housing and sewage. Among the vilified "technical" solutions was $\mathrm{BCG}^{49}$.

As the formal inauguration of ITC supported BCG vaccination approached, Raman's rhetoric sharpened. On $4^{\text {th }}$ February 1949 he gave a talk to a scientific society and thundered: I strongly protest in the name of India [...] against our boys and girls being made a sort of cannon-fodder and treated like guinea-pigs for the sake of experimentation $^{50}$. Raman's criticism cast a shadow over the inauguration ceremony on $15^{\text {th }}$ February; rather than praising their new tuberculosis control initiative, they were forced to defend BCG in the light of Raman's protest ${ }^{51}$. Raman and others continued to use People's health as a vehicle for criticising BCG up to 1951, but it was in the Spring of 1949 that the opposition was most energetic and visible. While the protests had limited impact outside the Madras area, it did succeed in getting the government of the Madras Province to postpone mass vaccination for some time ${ }^{52}$.

In 1954 BCG-vaccination was again launched in Madras. This time from the Southern city of
Coimbatore. Mahler was highly optimistic. In early 1955 he exulted: This explosive inauguration of the campaign caught the anti-propagandists asleep on their previous laurels, and some last minute efforts by them had no effect whatsoever ${ }^{39}$. By May, however, a new and more formidable opponent had emerged. It was Chakravarti Rajagopalachari, a veteran from the independence movement and a close associate of Gandhi. He had been Chief Minister in the Congress Government of the Madras Province from 1937 to 1939, and in 1948 he succeeded Lord Mountbatten to become the last Governor-General of India. In April 1952 he became once again Chief Minister of what had now become Madras State, a position he resigned in 1954 after falling out with the dominant faction of the local congress party. In addition, he was a friend of Raman ${ }^{53}$. As Chief Minister of Madras Rajagopalachari had internally voiced uneasiness with BCG and after he resigned this uneasiness developed into outright opposition ${ }^{52}$. Although Rajagopalachari as a Tamil Brahman was marginalized in a political environment increasingly dominated by the Dravidian, anti-Brahman ideology, he still had many admirers and followers in Madras and beyond.

Rajagopalachari used an invitation to speak at the annual meeting of the Tuberculosis Association in Madras to launch his public challenge to BCG. He pointed to the lack of scientific evidence to support BCG and more specifically he argued that since $80 \%$ of Indians tested positive to tuberculin - and thus were infected with tuberculosis bacteria - he believed they already possessed a "natural immunity" against tuberculosis. As Raman before him, he claimed that neither the safety nor the efficacy of BCG had been fully demonstrated. In a letter to the most important regional newspaper The Hindu he formulated his criticism in two questions: (1) Is there no danger in mass inoculation by live BCG? (2) Does the attenuated Bovine tubercle bacillus create an immunity against the normal human infection? Rajagopalachari was particularly concerned that BCG was based on live bacteria and that the vaccine might regain virulence in the human body. He warned: We cannot take chances with live bacilli whose behaviour and potentiality for harm have not yet been fully understood. Rajagopalachari did accept careful and controlled experiments with BCG, but given the uncertainties surrounding the vaccine he objected to the "mass" application of the vaccine: What one cannot, however agree to, is the injection into tens of thousands of our children, of live bacilli when we have 
no authority to claim certainty of harmlessness on the basis of the attenuation of those bacilli ${ }^{54}$. In the Summer of 1955 Rajagopalachari published a pamphlet entitled B.C.G. - Why I oppose it, in which he sharpened the language and directly raised the issue of Indian children being used as guinea-pigs: Indian Children are being offered for mass experimentation on the same plan as was put in operation among the people in the war-ravaged areas and uncivilized dependent communities ${ }^{55}$. This sounded very much like Raman's protest six years earlier and conveyed the same uneasiness that India adopted a public health intervention that might be either dangerous or insufficient, and which certainly appeared to be of a lower standard than those implemented in more developed countries.

Rajagopalachari's opposition had a clear impact on the BCG campaign. From May to August 1955 the numbers of tests completed in Madras State fell dramatically and in the neighbouring states Andhra Pradesh and Travancore-Cochin the effect of the opposition was also felt ${ }^{22,56}$. Rajagopalachari's protests were noted with approval by BCG sceptics and anti-vaccinationists all over India, and also in Ceylon, Burma and England ${ }^{52}$. Although most effective in 1955 Rajagopalachari continued to trouble the planners of the BCGcampaign for nearly two years. By early 1957, however, the strenght of the campaign seemed to have seems to have ebbed away. The resistance against BCG spearheaded by Raman and Rajagopalachari between 1948 and 1957 was arguably the most vocal protest against a vaccine in the decades after WWII. Its many facets has been analysed by Christian McMillen and me in greater detail elsewhere ${ }^{52}$, and here I shall limit myself to some brief observations.

First, both Raman and Rajagopalachari took great care to position themselves as believers in Western medicine. In August 1950, for example, People's Health wrote approvingly about Waksman's discovery of Streptomycin, the first antibiotic effecacious against tuberculosis, and expressed a hope that Waksman "will soon come out with a more wonderful drug" 57 . Similarly, Rajagopalachari supported the use of another antibiotic drug against BCG, isoniazid (INH). Significantly, Rajagopalachari also supported vaccination against smallpox ${ }^{58,59}$. In B.C.G. - Why I oppose it, he began by assuring the reader he was not “against modern 'western' therapy or modern science" 55 . Raman and Rajagopalachari were surprisingly well informed about the controversies surrounding BCG among medical ex- perts and their periodicals and pamphlets were full of references to the newest scientific medical literature, such as Journal of the American Medical Association, Lancet and even Acta Tuberculosae Scandinavica. When the renowned American tuberculosis expert Caroll Palmer - who for a time worked for ITC - in October 1949 declared that there was no strict scientific proof of the efficacy of BCG, Raman instantly (within one month) passed on this opinion to the readers of People's Healt ${ }^{60}$. Six years later the balanced views of Palmer were eagerly quoted by Rajagopalachari ${ }^{55}$. The attacks on BCG vaccination by Raman and Rajagopalachari were, therefore, never a general attack on Western medicine or science as such. In this way they made sure that they could not simply be dismissed as irrational or "emotional" voices from the East.

Second, behind the specific criticism of BCG loomed the larger issue of the nature of the postcolonial Indian state. Here, however, Raman and Rajagopalachari differed. Raman was a believer in the doctrine of social medicine and to him BCG was a "cheap" solution compared to the much more ambitious and interventionist "environmental hygiene", which he advocated ${ }^{61}$. A key point of reference for Raman was the report of the Bhore Committe. Published in 1946, this report had adopted the position of social medicine and advocated the future system of public health in India be based on a strong interventionist state. Quoting the report Raman asserted that in the campaign for improved health, drugs, vaccines and sera can in no way replace such essentials as a hygienic home, good food, fresh air and a safe water-supply ${ }^{62}$. Raman, in short, wanted a stronger and more interventionist "welfare" state. Rajagopalachari, by contrast, turned more and more hostile to the "big" state philosophy in Nehru's India. One of Rajagopalachari's biographers has argued that the period after 1947 saw his "paradoxical transformation from being an exponent of the authority of the state into one of its most mordent critics" ${ }^{33}$. In 1959 he was the leading figure in the establishment of the conservative Swatantra Party, which saw "statism" as the most important issue on which the Congress had to be opposed ${ }^{64}$. This suggests that Rajagopalachari's opposition was directed as much against the prevailing state ideology as against the vaccine itself. He could hardly have picked a more powerful symbol of the modernist pretension early independent India, than this massive effort to inject a contested vaccine into the body of every young Indian. 
Vaccination against smallpox in India also faced protests and opposition, but never on this scale and of this type. Sanjoy Bhattacharya has identified a variety of civilian attitudes to vaccination, including opposition linked to larger political debates, but notes that it was relatively easy to silence this opposition ${ }^{3}$. Similarly, Paul Greenough has studied the use of coercion in the final stages of the smallpox eradication campaign in India and Bangladesh, but the forms of resistance charted by him were local and spontaneous $^{65}$. It is obvious that the contested nature of BCG made it a much easier target for opponents than the celebrated vaccine against smallpox. It is equally clear that the specific and scientifically informed criticism of BCG opened for a criticism of a more general nature. As a vaccine with a problematic past and of an uncertain efficacy, BCG was particularly well suited as a platform for articulating general protests against prevailing processes of modernization. In post-colonial India, it did not matter whether these protest demanded a more ambitious welfare state or less state intervention.

\section{Conclusion}

The purpose of this article has been to remind the reader that the history of vaccination is diverse and multifaceted. Thus, the history of mass BCG vaccination in India deviates in a number of ways from the "original", celebrated - and eventually extremely successful - history of smallpox vaccination. This is not surprising, as tuberculosis biologically is very different from smallpox and BCG very different from the cowpox based vaccines. I have identified three specific areas, in which the course of BCG vaccination differed from vaccination against smallpox. First, the procedure of BCG vaccination was medically and logistically more complex. This meant that the procedure had to be modified in poor, populous countries like India. In a global perspective, therefore, BCG vaccination was less uniform than vaccination against smallpox. Second, as tuberculosis lacked the drama of smallpox and BCG never entailed a promise of eradication, it was more difficult for the campaign leaders to impress "fighting spirit" and enthusiasm into the field staff. The BCG campaign, therefore, suffered more from recruitment problems and a lax working ethos than the more "heroic" campaign against smallpox. Finally, the contested nature of BCG made it vulnerable to criticisms articulated from within the paradigm of scientific, "western" medicine. This turned BCG into a vehicle for the articulation of concerns about more general processes of post-colonial modernization. The vaccine against smallpox was significantly less suited for this purpose.

\section{Acknowledgements}

A version of this article was presented as a paper at the international symposium Smallpox eradication after 30 years: lessons, legacies and innovations, hosted by the Oswaldo Cruz Foundation, Rio de Janeiro, $24^{\text {th }}$ to $27^{\text {th }}$ August 2010. I am grateful to the organizers - particularly to Gilberto Hochman and Sanjoy Bhattacharya - for inviting me to this highly stimulating meeting. I am also grateful to the Wellcome Trust for financing my trip to Rio de Janeiro. 


\section{References}

1. Encyclopaedia Britannica. [site]. [cited 2010 sep. 14]. Available from: http://www.britannica.com/EBchecked/topic/621274/vaccine (accessed September 14, 2010).

2. Arnold D. Colonizing the body: State medicine and epidemic disease in nineteenth-century India. Berkeley: University of California Press; 1993.

3. Bhattacharya S. Expunging variola: the control and eradication of smallpox in India 1947-77. Delhi: Orient Longman: 2006.

4. Henderson DA. The miracle of vaccination. Notes and Records of the Royal Society of London 1997; 51(2):235-245.

5. Bhattacharya S, Brimnes N, editors. Reassessing smallpox vaccination, 1789-1900. Bulletin of the History of Medicine 2009; 83(1):1-16.

6. Henderson DA. The global eradication of smallpox: historical perspectives and future prospects. In: Bhattacharya S, Messenger S, editors. The global eradication of smallpox. Hyderabad: Orient Blackswan; 2010. p. 7-35.

7. Encyclopaedia Britannica. [site]. [cited 2010 sep. 14]. Available from: http://www.britannica.com/ EBchecked/topic/608235/tuberculosis (accessed September 14, 2010).

8. Encyclopaedia Britannica. [site]. [cited 2010 sep. 14]. Available from: http://www.who.int/mediacentre/factsheets/fs104/en/index.html (accessed September 14, 2010).

9. Mahler H. Quarterly Field Report, $3^{\text {rd }}$ quarter 1953, 20 October 1953. UN Archives (Unicef), Box CF/ RA/BX/PD/1962/T008, folder A122.

10. Feldberg GD. Disease and class: tuberculosis and the shaping of modern North American society. New Brunswick: Rutgers University Press; 1995.

11. Bryder L. "We shall not find salvation in inoculation": BCG vaccination in Scandinavia, Britain and the USA, 1921-60. Social Science \& Medicine 1999; 49(9):1157-1167.

12. Menut P. The Lübeck catastrophe and its consequences for anti-tuberculosis BCG-vaccination. In: Moulin AM, Cambrosio A, editors. Singular selves: historical issues and contemporary debates in immunology. Paris: Elsevier; 2001. p. 202-210.

13. Undated press note (but the note is accompanied by a covering letter dated 28 May 1948). Tamil Nadu State Archive, Health Department, no. 809, 1950.

14. Brimnes N. Vikings against tuberculosis: the International Tuberculosis Campaign in India 1948-51. Bulletin of the History of Medicine 2007; 81(2):407430 .

15. Second Five Year Plan, chapter 25 Health, Para 37. Available from http://planningcommission.nic.in/ plans/planrel/fiveyr/welcome.html (accessed September 14, 2010)
16. Ali PM. Quarterly Field Report, $4^{\text {th }}$ quarter 1958,16 January 1959. UN Archives (Unicef), Box CF/RA/ BX/PD/1962/T070, folder B176.

17. Final Report of the International Tuberculosis Campaign. Copenhagen: Unicef; 1951

18. Mahler H. Final Report on India BCG. UN Archives (Unicef), Box CF/RA/BX/PD/1962/T008, folder A124.

19. Ali PM. Quarterly Field Report, $2^{\text {nd }}$ quarter 1955,20 July 1955, p. 4-5. UN Archives (Unicef), Box CF/ RA/BX/PD/1962/T008, folder A124.

20. Ali PM. Quarterly Field Report, $4^{\text {th }}$ quarter 1956,21 January 1957, p. 2-3. UN Archives (Unicef), Box CF/RA/BX/PD/1962/T033, folder 542.

21. Letter from Rasthi MA (New Delhi) to Keeny S (Bangkok), 27 July 1959. UN Archives (Unicef), Box CF/RA/BX/PD/1962/T070, folder B176.

22. Amrith SS. Decolonizing international health: India and South East Asia, 1930-1965. Basingstoke: Palgrave MacMillan; 2006.

23. Ali PM. Quarterly Field Report, $3^{\text {th }}$ quarter 1960,31 October 1960, p. 1. UN Archives (Unicef), Box CF/ RA/BX/PD/1962/T102, folder B695.

24. Monthly Statistical Report on Tuberculin Testings and BCG Vaccinations for December 1963. UN Archives (Unicef), Box CF/RA/BX/ED/X/1947/T017, folder A194.

25. International Tuberculosis Campaign 1949: "Report to Unicef Medical Sub-committee", January 1949, p. 2. Danish National Archives no. 7369, Box 2 (D).

26. Second Annual Report of the International Tuberculosis Campaign. Copenhagen: ITC; n.d.

27. Mass BCG Vaccination Campaigns: a practical guide. Neuilly-sur Seine: Unicef; 1953.

28. Proceedings of Scandinavian Coordination Committee, 13 August 1949, p. 8-9. Danish National Archives no. 7369, Box 2 (C).

29. Letter from Lauritzen LB to Holm J, 14 September 1949. Danish National Archives no. 6790, Svend K. Svendsen, Box 1

30. Letter from Lauritzen LB to ITC, 3 October 1949. Danish National Archives no. 6790, Svend K. Svendsen, Box 1.

31. Benjamin PV. Anti-tuberculosis organisation for India. Proceedings of the Seventh Tuberculosis Workers Conference held in Bombay November 1949; Nov. 21-29.

32. Holm J. Report on visit to India, February-April 1951. Danish National Archives no. 7369, Box 4 (F.i/J. Holm).

33. Recommendations of the $2^{\text {nd }}$ BCG Conference in India. Annex 8 to [31]

34. International Work in Tuberculosis 1949-1965. Geneva: WHO; 1965. 
35. Mahler H. Quarterly Field Report, $4^{\text {th }}$ quarter 1953 , 19 January 1954. UN Archives (Unicef), Box CF/ RA/BX/PD/1962/T008, folder A122.

36. Mahler H. Progress report for the period from July, 1952 to June 30, 1953. UN Archives (Unicef), Box CF/RA/BX/PD/1962/T008, folder A122.

37. Mahler H, Ali PM. Review of Mass BCG Project in India. Indian Journal of Tuberculosis 1955; 2(3):108116.

38. Mahler H. Some of the conditions necessary for the development of an efficient mass vaccination programme. Speech delivered at a BCG conference in New Delhi, 18 December 1952. UN Archives (Unicef), Box CF/RA/BX/PD/1962/T008, folder A122.

39. Mahler H. Quarterly Field Report, $4^{\text {th }}$ quarter 1954, 20 January 1955. UN Archives (Unicef), Box CF/ RA/BX/PD/1962/T008, folder A123.

40. Ali PM. Quarterly Field Report, $2^{\text {nd }}$ quarter 1956,1 August 1956. UN Archives (Unicef), Box CF/RA/ BX/PD/1962/T033, folder A542.

41. Ali PM. Quarterly Field Report, $1^{\text {st }}$ quarter 1957, 27 April 1957. UN Archives (Unicef), Box CF/RA/BX/ PD/1962/T033, folder A542.

42. Ali PM. Quarterly Field Report, $4^{\text {th }}$ quarter 1959,19 January 1960. UN Archives (Unicef), Box CF/RA/ BX/PD/1962/T102, folder B695.

43. Mahler H. Quarterly Field Report, $1^{\text {st }}$ quarter 1954 , 23 April 1954. UN Archives (Unicef), Box CF/RA/ BX/PD/1962/T071, folder B178.

44. Mahler H. Quarterly Field Report, $2^{\text {nd }}$ quarter 1954, 25 July 1954. UN Archives (Unicef), Box CF/RA/ BX/PD/1962/T008, folder A123.

45. Svendsen SK. Fra BCG Kampagnen I Indien, report dated 11 August 1949. Riksarkivet, Stockholm: Svenska Röda Korsets Arkiv. Internationella Avdeling. Tuberkulos bekämmandet 1947-51. Overstyreslsens Tuberkuloskommittee B, v. 2 (my translation).

46. Mahler H. Report for the months of September and October 1951; n.d., p. 3, UN Archives (Unicef), Box CF/RA/BX/PD/1947/T016, folder A137.

47. Vyas BP. History of the BCG Vaccination Campaign in the City of Baroda. Manuscript, n.p., n.d.

48. Ali PM. Quarterly Field Report, $2^{\text {nd }}$ quarter 1959,15 July 1959, p. 1. UN Archives (Unicef), Box CF/RA/ BX/PD/1962/T070, folder B176.

49. People's Health 1948; 3(2):53. The expert was not from ITC. It is more likely that reference is made to a WHO consultant present when BCG was first used in India in August 1948.

50. Indian Express 1949; Feb 5. Reproduced in People's Health 1949; 3(5):198.

51. People's Health 1949; 3(5):222.
52. McMillen CW, Brimnes N. Medical modernization and medical nationalism: resistance to BCG vaccination in postcolonial India, 1948-1955. Comparative Studies of Society and History 2010; 52(1):180209.

53. C. Rajagopalachari Papers. Instalment V, Correspondence with People's Health, editor. Nehru Memorial Library, New Delhi.

54. The Hindu 1955; May 17.

55. Rajagopalachari C. B.C.G. - Why I Oppose It; n.p., n.d.

56. Letter from Larsen, P. (Unicef, New Delhi) to Davies, TG (Unicef, New York) 17 September 1955. UN Archives (Unicef), Box CF/RA/BX/PD/1962/T008, folder A124.

57. People's Health 1950; 4(11):459.

58. The Hindu 1955; May 8.

59. The Hindu 1955; Nov 23.

60. People's Health 1949; 4(2):56.

61. People's Health 1949; 3(5):203-204

62. People's Health 1949; 3(5):196.

63. Copley A. The political career of C. Rajagopalachari 1937-1954: a moralist in politics. Madras: MacMillan; 1978.

64. Erdman HL. The Swatantra Party and Indian conservatism. Cambridge: Cambridge University Press; 1967.

65. Greenough P. Intimidation, coercion and resistance in the final stages of the South Asian smallpox eradication campaign, 1973-1975. Social Science \& Medicine 1995; 41(5):633-645.

Artigo apresentado em 31/7/2010

Aprovado em 6/10/2010

Versão final apresentada em 12/10/2010 